\title{
Rethinking a new transition finance paradigm for addressing the climate crisis in Africa
}

Michael Zisuh ( $\nabla$ michael.ngoasong@open.ac.uk)

Ngoasong https://orcid.org/0000-0002-0612-0797

\section{Short Report}

Keywords: Climate crisis, energy transition, impact investment, Sub-Saharan Africa

Posted Date: October 29th, 2021

DOI: https://doi.org/10.21203/rs.3.rs-1028661/v1

License: (c) (i) This work is licensed under a Creative Commons Attribution 4.0 International License. Read Full License 


\begin{tabular}{|c|c|}
\hline$\approx$ & 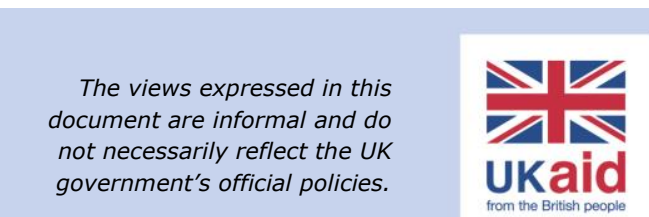 \\
\hline
\end{tabular}

\title{
Rethinking a new transition finance paradigm for addressing the climate crisis in Africa
}

\author{
Michael Zisuh Ngoasong ${ }^{1 *}$
}

\section{Key Messages}

- Transition finance vehicles in Africa should aim to transform 'brown' (polluting) into 'green' (renewable) industries.

- Key instruments include green bonds for specific environmental projects, grants/guaranties to support private investments that target access to energy for the poor, and patient capital investments into growth sectors focused on environmental, social, and governance targets.

- National energy policy should connect innovative market-based solutions (e.g., mini grids) to centralized (e.g., national grid) systems to strengthen governance.

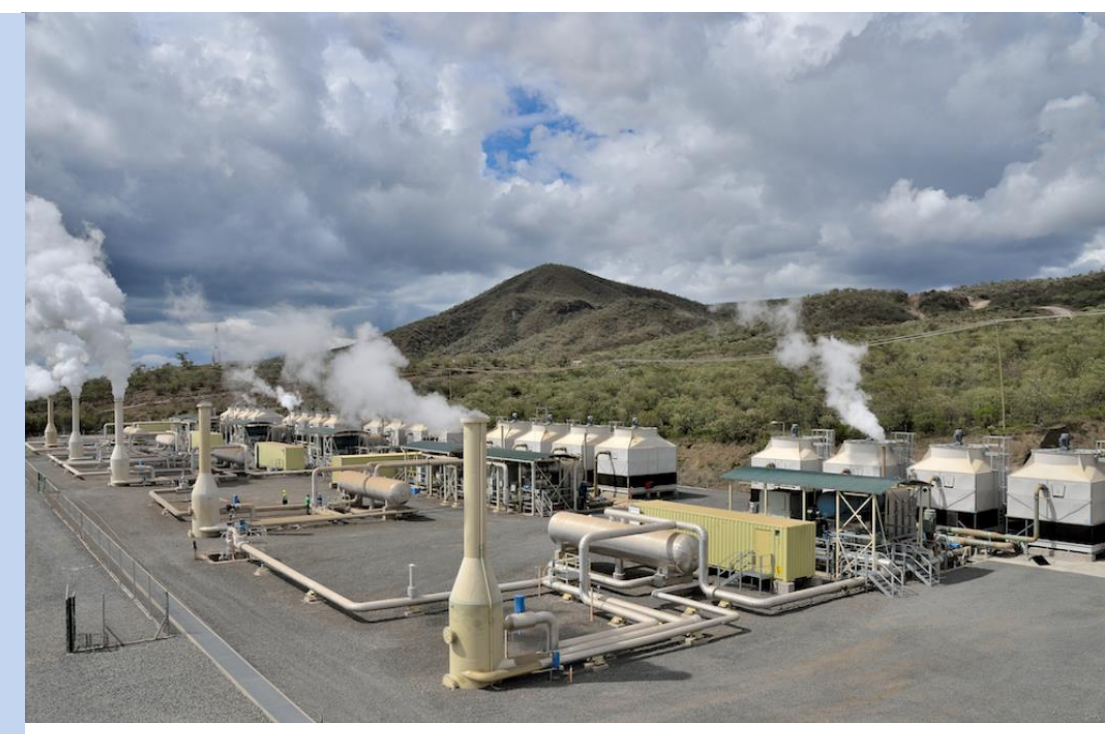

Wellhead plants of Green Energy Geothermal (GEG) at Olkaria, Kenya (https://gegpower.is/tag/wellhead/). Despite high investment costs, geothermal power provides renewable fuel with very little carbons, making it one of the most affordable forms of renewable energy [6].

\section{Introduction}

For African governments, this policy brief suggests that incorporating financial instruments into policy packages to enable the successful transformation of 'brown' (polluting) into 'green' (renewable) industries can ensure that private sector investments are effective in addressing the climate crisis. It also helps address UN Sustainable Development Goal 7 to ensure access to affordable, reliable, sustainable, and modern energy [1][5]. This reflects the highly ambitious policy targets set by African governments, such as Kenya, Ghana, Nigeria, and South Africa [1][2][6]. Alongside an emphasis on environmental, social, and governance targets, falling technology costs make renewable energy a cost-effective alternative to fossil fuels [12].

Africa faces three key challenges when leveraging transition finance towards addressing the climate crisis. First, energy security. In 2019 about 50\% lacked access to energy, under $30 \%$ could access clean cooking fuels [4], and 588 million lacked access to electricity [5]. Second, major sources of
Africa's energy are viewed as polluting. The growing use of diesel generators pollutes the environment through noise and smell from diesel use [8] [13], alongside recent (e.g., in Ghana) and established petroleum production (e.g., in Nigeria). Even hydropower, wind energy, and geothermal power suffer from unreliability due to equipment that requires additional costs in maintenance [6]. These are features of brown industries that are in need of greening. Third, alongside the benefits of increased access to energy, climate change mitigation, and lower fossil fuel use, there are potential risks and costs to achieving a low-carbon energy transition. In South Africa, the impact of a low-carbon transition (includes lost export revenue and lost local markets for coal and liquid fuels) is US\$ 120 billion, while US $\$ 44$ billion (or $12 \%$ of GDP) is needed to finance the transition [7]. Africa needs US\$70 billion annual investments in renewable energy projects by 2030 to address energy security and transition [4] [5]. 
For African governments, the above challenges reflect their struggle to reconcile aspirations for economic development against fighting the climate crisis and what might be needed to simultaneously pursue both. Addressing the climate crisis in Africa needs to be understood not as an energy transition, but as modernizing and scaling-up [3] from 'brown' (polluting) to 'green' (renewable) industries. This brief asks, "what investment-ready instruments and policy packages can unlock this type of energy transition?" This question is addressed by drawing on lessons from Ghana, Kenya, Nigeria, and South Africa, which are among the leading energy transition countries in Africa.

Building on ongoing research on impact investing and inclusive development in Africa [9], this policy brief combines a synthesis of existing evidence with analysis of 23 stakeholder interviews with Fund Managers, banks, and consulting firms who are undertaking impact investing activities in Sub-Saharan African countries, with a focus on Ghana, Kenya, Nigeria, and South Africa. The stakeholder interviews were unstructured in that they did not stick to a pre-defined set of questions; rather they were open-ended to allow stakeholders to discuss climate-related challenges, financial instruments, and how these can be incorporated into policies in the study countries. Comparing historic market prices and green finance targets provides insights into the metrics and processes behind selecting appropriate portfolio investments for green versus brown industries. The data were assessed to uncover the instruments and policy packages that can enable Sub-Saharan African countries to unlock sustainable investments.

\section{Results}

Three credible opportunities for formulating investment policies that encourage the transition from brown to green industries are identified:

(1) Green bonds as stable and sustainable low-carbon instruments are in need of development and wider deployment. Green bonds are fixed-income instruments designed to support specific climate-related or environmental projects. They typically provide incentives for investors to combine grants (recoverable and non-recoverable), loans at concessional rates and terms, and equity. Beginning with the World Bank's issue of the first official green bond in 2009, around $\$ 157$ billion had been issued by 2019. For instance, the South Africa Green Fund was introduced in 2012 and managed by the Development Bank of Southern Africa on behalf of the Department of Environmental Affairs. An evaluation of the fund found evidence of active government support, a strong governance system (representation from diverse sectors), long-term financial commitment (10 to 15 years), and the strong legal and financial practices required of an environment-focused finance vehicle [10]. Nigeria,
Kenya, Namibia, and South Africa have developed green bond markets and are sources of lessons for other African countries. A recent feasibility study for developing a green bond market in Ghana is benchmarked against these four countries [11].

(2) Investment policies that enable a substantial reduction in carbon emissions, while ensuring access to energy for the poorest households/communities. Exemplar policies in the study countries include Kenya's Feed-in-Tariff for Wind, Biomass, Small Hydro, Geothermal, Biogas, and Solar that was introduced in 2008 and recently added to the Energy Act, 2019, and the 2011 Renewable energy auctions in South Africa [6] [15]. The evidence reveals that these policies are only effective where there are transparent competitive tenders/auctions programmes, auditable nonnegotiable contracting, and enforceable targets for reductions in carbon emission. Investment policies should also provide fiscal incentives to attract renewable energy investments, as decentralized green alternatives to existing brown technologies. The evidence across Ghana, Kenya, Nigeria, and South Africa reveals how the geographic distance to the national grid makes it costly to connect rural communities to the national electricity system. Attractive fiscal policy instruments, such as Pay-AsYou-Go solar, electric utility quota obligation, net metering and premium payments [6] can be applied to micro-grid projects to provide access to businesses and households with attractive alternatives that can help reduce the dependence on back-up generators that are polluting and costly to maintain [8] [13].

(3) Investment policies that attract transition finance into economic activities that support net-zero emissions, but which are not primary sources of energy. The Global Impact Investing Network estimates US $\$ 6.8$ billion impact investment asset allocation to West Africa, US\$ 7.8 billion to East Africa in 2014 [12] and at least US\$ 12 billion to Sub-Saharan Africa [10]. Bank-based and capital market-based fund managers' report that impact investments channelled into small and medium-sized enterprises [12] in real estate development, waste management/recycling, and supply chain management (e.g., packages) are producing favourable targets for environment, social, and governance (ESG) outcomes. Favourable outcomes uncovered in this study include the financial performance that arises from reductions in energy consumption, waste generation, and carbon emissions (environment), boost to employees due to stronger social credibility, stronger community and government relations (social), and greater strategic support arising from compliance with regulatory and legal requirements (governance). These arise from a growing demand from investors, consumers, and governments for greater standards of sustainability in businesses practices. 


\section{Recommendations}

(1) Investment policies, such as transition bonds, can sustain measures to address the climate crisis by prioritizing the setting up of transparent governance framework for attracting investments and for auditing targets for reductions in carbon emissions. Policies should also be aimed at greening (improving or cleaning) the brown (dirty and polluting) industries by transforming the practices of the least sustainable sectors and companies, while improving access to clean energy.
(2) The transition finance paradigm for addressing the climate crisis in Africa should combine three types of transition activities, alongside setting up a transparent governance framework for attracting investments and auditing targets for reductions in carbon emissions: (1) green bonds to support specific environmental projects, (2) ensuring access to energy for the poor (e.g., mini-grids) and (3) nonenergy products and services that ensure that the economy transitions to net-zero emissions (e.g., real estate sector).

\section{References}

[1] Kenya Bankers Association. 2020 Report on the State of Sustainable Finance in Kenya's Banking Industry. (2020).

[2] Marbuah G. Scoping the sustainable finance landscape in Africa: The case of green bonds. (2008)

[3] PAGE. Green Finance Study in Ghana: Baseline Report. (2018)

[4] Ackah I., Graham E. Meeting the targets of the Paris Agreement: an analysis of renewable energy governance systems in West Africa. (2020)

[5] World Bank. Tracking SDG 7: The Energy Progress Report 2021. (2021)

[6] Kazimierczuk A. H. Wind energy in Kenya: A status and policy framework review. (2019).

[7] Walwyn D. R. Turning points for sustainability transitions: Institutional destabilization, public finance and the techno-economic dynamics of decarbonization in South Africa. (2020)

[8] Afful-Dadzie A., Mallett A., Afful-Dadzie, E. The challenge of energy transition in the Global South: The case of electricity generation planning in Ghana. (2020).
[9] Ngoasong M., Paton R., Korda A. Impact investing and inclusive business development in Africa: A research agenda. (2015)

[10] Mohamed N., Maitho E., Masvikeni E., Fourie R., Tilly M., Zondi, N. The Green Fund of South Africa: Origins, establishment and first lessons. (2014).

[11] FSD Africa. Feasibility Study for Development of a Green Bonds Market in Ghana. 2021

[12] Lamptey, R. O. The influence of bank-based and capital market-based impact investments on SME financing in Ghana: governance, strategy change and impacts. (2020).

[13] Rolffs, P., Ockwell, D., Byrne, R. Beyond technology and finance: pay-as-you-go sustainable energy access and theories of social change. (2015).

[14] Global Impact Investing Network. Annual Impact Investor Survey. (2019).

[15] Eberhard A., Kåberger T. Renewable energy auctions in South Africa outshine feed-in tariffs. (2016).

\section{Notes}

Climate Compatible Growth (CCG) programme: CCG is funded by the UK's Foreign Development and Commonwealth Office (FCDO) to support investment in sustainable energy and transport systems to meet development priorities in the Global South.

\author{
Author Information \\ Affiliation \\ 1 Senior Lecturer in Management, Open University \\ Business School, UK, \\ Corresponding author: \\ Email: michael.ngoasong@open.ac.uk.
}

